placed in a difficult position. Is each to decide for himself, or shall the lex non scriptc be revised? Mr. Hutchinson has suggested that "the responsibility of decision be left to the licensing bodies, as to who are to be admitted to the privileges of formal consultation and who excluded."

But with the Royal Commission on the Medical Acts still sitting, what are the chances of the corporations undertaking new, delicate, and gratuitous daties? If they were so disposed, what are the probabilities of their commanding the assent of the profession after the manner in which they have dealt with the great subjects of profe-sional education and examination, which by tradition and statute are peculiarly their own ?

In a minor degree any one of us may at any moment be met by the difficulties of the Beaconsfield incident; and it is very important to obtain, so far as practicable, an authoritative settlement of the question at issue, Are homcopaths to be met in consultation? Having just emerged from the great International Congress, most of us are for the time satiated with public diseussion. Nevertheless, so important to the profession, especially in its relations to the public, is the question on which I have ventured to address you, that it cannot longer be left in its present state without discredit, and possible practical mischief. My suggestion is that it be considered in a conference of representative members of the profession. The manner in which they shall be called together, and under whose presidency, are questions of detail which will present no difficulty, if the proposal meet with favour. It seems almost needless to add that the discussion should be openly and fairly conducted. It would be too much to bope that the decision could be final, but it assuredly could not fail to have great weight.

I am, Sir, your obedient servant,

Birmingham, August 20th, 1881. SAMPSON GAMGEE.

\section{ON THE PERIODICITY OF FILARIAL MIGRATION.}

To the Editor of THE LANCET.

SIR,-In an annotation last week you draw attention to a recent paper on the above subject by Dr. Patrick Manson, published in the Journal of the Quekett Microscopical Club. Many of your readers may be interested to learn that I have under my care at the London Hospital a patient from India suffering from hæmato-chyluria, whose blood and urine contain the filaria sanguinis hominis in large numbers. The observation of this case completely confirms Dr. Manson's statements as to the periodicity of filarial migration. In the daytime the patient's blood is practically free from filariæ; but when examined at night, each slide contains large num. bers of the nematodes in a most active condition. As many as 125 have been counted in a drop of blood beneath a 5 inch cover glass at twelve o'clock at night. I have, by the kindness of Dr. Spencer Cobbold, compared these filariæ with those from India sent by Dr. Lewis, with filariæ from the mosquito from China sent by Dr. Manson, and with filariæe from the blood and mosquito from Australia sent by Dr. Bancroft, with the result of showing the identity of the filarige from these various sources.

At the forthcoming session I shall show the case, and give a full account of my observations at one of the Medical Societies. Meanwhile, as I know of no recorded case where the filariæ have been found in England, and as the subject is of great interest in so many respects, I have thought it desirable to send you this preliminary notice. I shall be pleased to show the case to any interested in the subject. Yours faithfully,

Finsbury-square, Aug. 23rd, 1881.

$$
\text { StePhen Mackenzie, M.D. }
$$

\section{DR. BRAXTON HICKS' PAPER ON INTERMIT- TENT CONTRACTION OF THE UTERUS.}

\section{To the Editor of THE LANCET.}

SIR,-In your notice of the papers read before the Obstetric Section of the International Congress you allude to my paper on the Intermittent Contraction of the Uterus, and remark that $I$ had failed to mention in my paper that these contractions were not diagnestic of pregnancy, for they are found to occur in elastic fibroid tumours of the uterus. I was too unwell to be present at the reading of my paper, or should have answered a similar observation made by one of the speakers. Permit me to make my rejoinder in your columns. I have paid attention to this subject for twelve or thirteen years, and have inade use of it in a very large number of cases. I have never found any condition of the uterus, but that of preonincy, attended with these frequent contractions. I have never heard of anyone who has narrated such a case. The only writer with whom I am acquainted who says anything about it is the late Dr. Tanner, and he merely makes an assertion in an off-hand way. I am ready to admit that a change of density gradually takes place for some days before the "period" in cases of elastic fibroids, but this change is entirely different from the contractions occurring every five to twenty minutes in pregnancy. Till I have better evidence on the matter other than exi-ts at present, I must maintain that the intermittent contractions of the uterus are a very reliable sign of intra-uterine pregnancy. The only case at all likely to give rise to error is the uterus distended by detained menses. As this can only occur from occlusion, it can be readily ascertained by vaginal examina. tion. But $I$ have no proof that contractions oceur in this state; for practical purposes the vaginal examination will set it at rest. Supposing it were hereafter shown that elastic fibroids became altered in density every five to twenty minutes in all cases where amenorrhoa was present, then we may be certain, for these tumours have no such symptoms, I remain, Sir, yours truly,

J. BRaxton Hicks.

George-street, Hanover-square W., Aug. 18th, 1881.

\section{MOSQUITO BITES.}

\section{To the Editor of THE LANCET.}

SIR,-It is pretty well known in London that genuine mosquitoes have appeared in at least one large hotel. Two cases of mosquito bites of unusual severity have recently attracted my attention; and one of them seems to me to deserve notice.

In the first case, a medical man was so cruelly bitten on the face and head that he was much disfigured. Each bite was the seat of a small ecchymose; and a minute bloody crust occupied the point where the poison had entered. This gentleman, who had had long experience of the tropics, and had gone through the usual experience of mosquitoes, had never before suffered so much from this tormenting insect. $\mathrm{He}$ brought me specimens caught in flagrxnte delicto, and in general appearance they resembled the ordinary tropical mosquito. The irritation produced in the spots led him to suspect that an unusually venomous variety had established itself in London.

A few days ago a young lady consulted me for mosquito bites of an unusually severe character. She had been residing in the same hotel in which my filend had been bitten, and had had even worse experience. The bites were chiefly on the nose and upper parts of the cheek, and were seen as large raised flattened vesicles-not unlike a vaccine pustule - with a central depressed dark point, which corresponded to the point bitten. These vesicles har become confluent over the nose, and produced an appearance of impetiginous eczema, with well-defined borders.

As often happens when the face is the seat of a skin affection with exudation, the discharge had, on some parts of the cheeks and chin which had not been bitten, produced secondarily bullæ of what is often called impetigo contagiosa - simple superficial inflammation of the skin characterised by a bulla, and produced by various causes, often by simple eczematous fluid.

With one exception these two cases are the most severe cases of mosquito bites $I$ have met with, although at one time I had uuusual opportunities of observing such eases. The exceptional case was that of a stout woman, who was severely bitten during the first night she spent in a tropecal harbour. Her body was covered with round plaques of severe inflammation averaging nearly the size of it threepenny piece, each plâque having its minute central point. There was high fever, and the patient's life was endangered fur several days.

It would be interesting to know whether other victims of the recent inroad of mosquitoes into London have suffered with equal severity. Yours obediently.
Queen Anne-street, July 27th, 1881.
G. 'ThIN, M.D. 